\title{
THE LATEST MUHAMMADAN MARE'S NEST
}

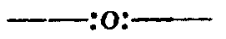

Some of our Muslim friends, and especially those of them who have received a European education, have of late years distinguished themselves by making discoveries in connexion with their own religion and the Christian, which, if not always reliable, are generally amazing and sometimes amusing. The credulity on their part.which these discoveries,- - or inventions, - reveal, is at least as striking as the ingenuity to which they testify. The theory that Jews and Christians at some period, whether before or after Muhammad it is hard to say, laid aside their feelings of hostility to one another and conspired together to corrupt their own Holy Scriptures was devised by an older generation than the present. It must be admitted that few learned Muslims ever accepted such an absurdity, but it is still prevalent among the ignorant. The theory was doubtless invented to account for the numberless contradictions and the general want of harmony between the Qur'ân and the Books which it professes to have been sent down to confirm. But it fails to explain how Haman comes in the Qur'ân to be Pharaoh's wazîr and the Virgin Mary a "sister of Aaron."

Passing over this and other like theories, however, we find that quite recently certain great " discoveries" have been made which are of much interest to students of human errors. One of these discoveries is that the Qur'ân inculcates monogamy and condemns polygamyor, rather, as Mr. Amîr 'Alî says, polygyny. Another is that Muhammad himself indulged in polygamy to such an excess merely through tenderness of heart, which led him to take that strange method of protecting widows. The fact that he had made some of them widows in order to have the opportunity of thus taking care of them by making them his wives or concubines,- 
as he did Şafiyyah and Raị̣̂nah respectively,-is a mere detail. A third great modern discovery is that no reliance should be placed on the earliest and most celebrated Muslim historians, traditionists, and commentators, when they relate anything which a modern apologist deems discreditable to Muhammad, but that the very same writers are thoroughly reliable when they state anything in his favour. We wonder why this should be regarded all of a sudden as axiomatically true, but no Neo-Muhammadan writer deigns to enlighten our ignorance on the subject. We have to content ourselves with his ipse dixit,-and admire his assurance.

But the last and greatest of modern discoveries has been made by a certain Mr. Muhammad Tâhhiru't Tanîr, and is duly proclaimed by him in his little book entitled $A l$ 'Aqâidu ' $l$ Wathaniyyah fî 'd Diyânati' $n$ Nasrâniyyah ("The Heathen Doctrines in the Christian Religion"), recently published at Beirut. With charming irony the work is dedicated "to the Missionaries, the Crusaders of the Twentieth Century." As is clear from the title of the book, this valuable "discovery" is that nearly every tenet of the Christian faith is derived from the religions of the heathen! We are credibly informed that some of the more ignorant Muslims have already been found credulous enough to believe this true.

We began the perusal of the book with much interest, being anxious to discover whether the writer had really himself been deceived by certain ignorant English writers, or whether he merely wished to deceive his fellow-believers, so as to prevent them from accepting Christianity. His preface rather tends to suggest the latter motive, but we were inclined to take the former view as the more charitable of the two. At first sight this more favourable supposition seemed to be supported by the array of books which Mr. Tanîr gives as his authorities. This, indeed, led us very naturally to infer that the author had read most, if not all, of the volumes to which he appeals as the sources of his information. If he had really investigated the matter carefully, one would make allowance for the fact that he had been misled by ignorant writers and unreliable books. There 
would then be ground for the hope that, when his attention was called to the cause of his error, he would himself correct it, and thus contribute to the ultimate "victory of the truth," for which he professes to long. He tells us that his appeal is to "historical and archæological facts, about the evidence borme by which there is no doubt." $\mathrm{He}$ adds : "We have not adduced anything new of our own, but on the contrary we have brought forward well-established facts. Whoever entertains doubt about a single one of them need merely refer to their source" (the authority for them), "which we have mentioned under each subject. One of the strangest of chances is that all the books we have appealed to for evidence are the compositions of famous European Christian theologians" (p. 9). He then proceeds to devote four whole pages to a list of the books which he professes to have consulted, and which he would have us believe are the authorities that support the statements in his book. The innocent Muslim reader naturally infers that the writer, in his zeal for the truth, has really consulted these books. Such an inference would be wholly wrong, as we shall soon perceive.

When a scholar reads the list, he notices that it is strange in more ways than one. In the first place he wonders where in the world the writer managed to compile a catalogue containing so many utterly unreliable works. In fact those among them which a man of learning would venture nowadays to quote, such as the Bible and Farrar's Life of Christ, are very few. Besides any other faults which many of these books have, they are nearly all hopelessly out of date. Imagine a man venturing to rely upon Maurice's "Indian Antiquities,"a book published in 1794,--for information about India ! But this is merely one such instance. Such works are valuable only as shewing how ignorant of things Eastern even educated Europeans then were. Probably it is no exaggeration to say that there is not a single statement about Eastern religions made by Maurice which is really correct. But even the latest book in Mr. Tanir's list was published in 1882, not less than thirty-one years ago!

The question arose in our mind, How did the un- 
fortunate author of $A l$ 'Aqâid get such a list of books, and how did he so very cleverly avoid including a single modern and reliable work on Oriental Religions in his catalogue ? It was not difficult to solve the problem. We did so by opening the latest book in the list, an American work of no authority entitled "Bible Myths and their Parallels in Other Religions," by T. W. Doane. It then became evident that Mr. Tanîr had copied Doane's list of authorities (as given in pp. xi.-xxiii. of "Bible Myths"), with omissions, but with no additions of importance. He then proceeded to compile his book by translating selected passages from " Bible Myths," giving the references he found given in that book, but apparently without verifying them in a single instance. Hence $\mathbf{M r}$. Tanîr not only repeats Doane's blunders but adds a number of his own to them in the additions and explanations which he gives. Let one example of this be adduced. In the last line on p. 11 of $A l$ "Aqâid, Mr. Tanîr mentions as one of his " authorities" Guigniaut's "Monumental Christianity." Unfortunately for him, Guigniaut wrote no such book, so it would be difficult for his readers to consult it. The book is given as by Lundy in p. 12, and this time correctly. Guigniaut's book is " $\mathrm{La}$ Religion de l'Antiquité." But it is not without interest to enquire how the mistake originated. That again is clear. In "Bible Myths," p. 184, a footnote refers to Guigniaut's " Religion de l'Antiquite," as quoted by an (imaginative and unreliable) writer called Higgins. Immediately after, Doane proceeds to quote a sentence from Lundy's "Monumental Christianity." Mr. Tanîr copied this so carelessly that he took half of each of the two notes, and, therefore, speaks of Guigniaut's "Monumental Christianity,"-a book which never existed,-and refers his readers to it for a "fact" which is untrue !

Mr. Tanîr is not the only assailant of the Christian faith who has adopted such unworthy tactics. Mr. Howard Nash, in his "Pagan and Christian Parallels in the Light of Modern Thought," proves that " P. Vivian" (Mr. Phelips), in "The Churches and Modern Thought," has done just the same thing, even more dishonestly, by borrowing from Doane's book without any acknowledge- 
ment. But while we grieve that an Englishman should have disgraced the character of English anti-Christian literature in such a way, we are none the less compelled to condemn Mr. Tanîr for following such a bad example of unscrupulous conduct. It should be noted, however, that the delinquents in each case betray their own cause and exhibit their credulity and dishonesty in a striking manner. They both stake their faith upon a writer who, so far from being a "very great scholar" ("allamah), as Mr. Tanîr repeatedly styles him, was no scholar at all, as his book clearly shews. Moreover, he evidently possessed no critical acumen to prevent him from blindly accepting any statement, however baseless, which seemed to favour his own preconceived ideas.

Mr. Tanîr, while relying for his "facts" upon Doane, depends for his illustrations upon another equally credulous writer, Inman, whose book, "Ancient Pagan and Modern Christian Symbolism exposed and explained," 1869 , is as much marked by ignorance as by prurience. How much Inman knew of Oriental religions is well illustrated by what he says about Islâm : "A . . . pious Mahometan regards the Crescent as the passport to the realms of bliss "(p. vi.). Of course, our readers are aware that the Crescent is not really to the Muslim a religious symbol at all, but merely part of the Sultân of Turkey's coat-of-arms. Yet Inman is also dignified by Mr. Tanîr with the title $A l$ 'Allâmah!

As to Inman's illustrations, though he makes a wrong use of them, he is not quite so dishonest in the matter as is Mr. Tanîr. The latter, on p. 25, gives an indecent picture, which is copied from Plate vii. in Inman's book. Inman describes it (p. 5) as a "copy of an original drawing made by a learned Hindoo pundit for Wm. Simpson, Esq., of London, whilst he was in India studying its mythology." The thing is, therefore, of no antiquity or authority. Inman admits besides that the " crux ansata" was inserted by himself in place of a different symbol.

Mr. Tanîr, p. 57, produces a picture of Devakî and Krishna, copied from Inman, p. 17, who again takes it from Moor's " Hindû Pantheon," p. 59. Inman quotes 
Moor, who is quite unreliable. The words under Tanîr's picture, "Devakî, full of grace ; and her child, the god Krishna, appears in human nature," are not Moor's, nor are they Inman's. They are his own invention. Again and again (on the cover of his book, and also in p. 36 , and opposite p. 48) Mr. Tanîr reproduces a figure of a man with arms outstretched and the rays of the sun shining on him. In the last mentioned instance he describes this as representing "Krishṇa on the cross with a crown of gold on his head." The illustration is taken from Inman, p. 42, and the latter says that it is "from Higgins, who has copied it from Moor's 'Hindu Pantheon." "But Inman is honest enough to add, "Having been able recently to procure a copy of this work, I find that Moor distinctly expresses his opinion that it is of European and not of Indian origin, and consequently that it is worthless as illustrating the life of Cristna." Yet Mr. Tanîr ventures to use this picture as a strong proof of several things, among others of the " fact" that Krishna was believed to have been crucified! Of course, every scholar knows that such an idea has never been believed by the Hindus. On the contrary, the Vishnu Purâna (Part v., sect. xxxvii., šll. 61-67) tells how a hunter named Jarâ mistook the sole of Krishna's foot for part of a deer and killed him by shooting an arrow into it. Thus one of the bubbles which Mr. Tanîr blows on his own account is burst. The other "facts" which he borrows from his veracious "authorities " are equally easily disposed of. Our space permits us to shew this with regard to two or three only, but we have examined them all. Let us take a few instances of what Tanîr and his misleaders entitle "Virgin birth," in order to make this clear.

Doane,-for it is hardly worth while quoting Mr. Tanîr's extracts from his work,--shews his learning (?) by rendering "Heri Crishna" (it should be Hari Krishṇa, if anything) by "Crishna the Saviour"* (p. 112), and tells us that the Mahâbhârata was written "about the

\footnotetext{
* The meaning of the name Hari is disputed. It often means "brown," "bay," or "green," also " a monkey," "a jackal," "a lion," ete., etc.
} 
sixth* century B.C." (p. 113). He goes on to say, " Crishna was born of a chaste virgin called Devakî, who, on account of her purity was selected to become 'the mother of God" " (ibid.). Of course, he gives no authority for this statement. The Vishṇu Purâna informs us that Krishna was the eighth child of Devakî and her husband Vasudeva. So much for Virgin-birth in this instance. It states that "a portion" $\dagger$ of Vishnu "descended on thef earth" to become Krishna; and explains this by saying, "The supreme deity" (i.e., Vishnu) "plucked off two hairs, one white and one black, and said to the celestials, "These my hairs shall go down upon earth and shall relieve her of the burden of her distress . . . This my black hair shall become the eighth conception of the goddess-like Devakî, wife of Vasudeva, and shall destroy Kañsa, who is the demon Kâlanemi.' " $\ddagger$

How clever it was of the Evangelists to evolve from this rubbish,- written centuries after their deaths,--the sublime Gospel narrative! And how credulous unbelievers are to accept such a theory!

Another example to shew the gullibleness of these men will suffice. Mr. Tanîr (p. 82) gives a translation purporting to come from a Chinese book, the Fo-pen-hing. He takes it from Doane. In Doane's book it begins thus, "The attending spirits, $\S$ who surrounded the Virgin Mâyâ and the infant Saviour, singing praises of the Blessed One, said, 'All joy be to you, Queen Mâyâ,'" etc. This is very remarkable, is it not? It becomes somewhat less so when we learn that Doane is quoting from Bunsen's "Angel Messiah," and that the latter writer is the inventor of the whole of the above extract except the words, "All joy be to you," etc. These, and not the words which precede them, are from Beale's version of the Fo-pen-hing, p. 47. The fact is that the Buddhists have never believed in the Virgin Birth of Buddha. No religion except the Christian does hold such a tenet: though the Muslim who denies the Virgin Birth of the Lord Jesus

* Its date is not precisely known, but this is far too early.

† Vishnu Purâna, Pt. I., sect. 1, and Pt. V., sect. 2.

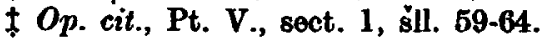

"Bible Myths," p. 148. 
Christ is attacking a doctrine which his own Qur'ân confirms.

Mr. Tanîr's attempt to trace the doctrine of the Trinity in Unity to heathen sources also breaks down hopelessly on examination. Here we take but a single example. Mr. Tanîr borrows from Doane, as usual. Doane depends very largely on Maurice in dealing with the Trimûrti, the supposed Hindû Trinity. Maurice holds that "the worship of a Trinity existed"... [in India] "fully 2,500 years ago, when Sanscreet was the current language of India," and that this is proved by the existence of the word Trimûrti. Now that Sanskrit has been properly studied, we know that the word Trimûrti is of comparatively modern origin, and does not occur in old Sanskrit works. Mr. Tanîr reproduces (p. 18) the three-headed figure of Siva still to be seen in the Elephanta Caves in Bombay harbour. Maurice writes of it thus : "Of stupendous antiquity,--antiquity to which neither the page of history nor human traditions can ascend,that magnificent piece of sculpture . . . in the cavern of Elephanta decidedly establishes the solemn fact that, from the remotest aeras, the Indian nations have adored a Tri-une Deity."* The Elephanta caves have been carefully studied since Maurice wrote in 1794, and it is now held that they were not formed before the ninth century of the Christian era, while the three-headed figure is sometimes thought to date from about 1300 A.D.

Mr. Tanî's misstatements are so numerous that it is difficult to know which to select as the final example of his credulous readiness to be deceived, which is equalled only by his unscrupulousness in adding from his own imagination such words as "the Father, the Son and the Holy Ghost" to passages which he quotes from Doane as translations from various heathen religious books, in order thus to deceive others. But perhaps the following instance may do as well us any other.

He states that the Hindû god Siva is represented in the form of a dove. This strange fiction seems to be due to confounding Siva with a fabulous King Sibi, regarding 
whom a story is told in various forms* in Hindû and Buddhist books. It is represented also in Buddhist sculptures-e.g., on the Amarâvatî tope, which dates from the early centuries of the Christian era. The simplest form of the tale runs thus. King Sibi was very kind to all alike. (The Buddhist accounts state that he was in reality Buddha in a previous state of existence). To test his self-sacrifice, Indra took the form of a hawk and pursued Agni (or, according to another account, Dharma-i.e., Virtue or Religion), who assumed the appearance of a pigeon as an illusion. The pigeon took refuge in King Sibi's bosom. The hawk demanded its surrender, reproaching the King with cruelty in depriving him of his natural food. The King, in order to save the pigeon and satisfy the hawk, offered to permit a quantity of flesh equal to the pigeon's weight to be cut from his own body. When this process began, it was found that the whole of his flesh was required in one scale to balance the pigeon in the other. Another story is that the compassionate King gave both his own eyes to Indra (Sakko), who in the disguise of a beggar asked for one of them. No form of this tale bears the very slightest resemblance to anything in the Bible, though it must be confessed that the likeness is as great in this as in any other matter to which Mr. Tanîr and his European "very learned men" refer. The pigeon in the fable is not identified with Siva, nor is the latter confounded with King Sibi, except perhaps by Tanîr \& Co.

It is impossible for us to congratulate Islâm on such "discoveries" as Mr. Tanîr fancies he has made in unearthing the ignorant blunders and dishonest pretences of such a writer as Doane, and then publishing them to the Arabic-speaking world as the results of his own efforts to secure the triumph of "the truth." The Religion of Islâm is worthy of a less credulous and a more honest champion.

W. St. Clair Tisdall.

* E.g., in the Kathâ-sarit-sáfjara, in the Jâtaka-mâlâ, in the Cariyố-pritaka, the Jâtakns, et.c. 